\title{
CYP3A5*8 Allele
}

National Cancer Institute

\section{Source}

National Cancer Institute. CYP3A5*8 Allele. NCI Thesaurus. Code C46023.

Human CYP3A5*8 allele is located in the vicinity of $7 \mathrm{q} 21.1$ and is approximately $32 \mathrm{~kb}$ in length. This allele, a variant form of the human CYP3A5 wild-type allele, encodes cytochrome $\mathrm{P} 4503 \mathrm{~A} 5 * 8$ protein. The CYP3A5*8 allele exhibits a clinically-relevant SNP (g.3699C > T) in exon 2 that results in a R28C coding change. This alteration in protein sequence decreases the enzymatic activity of the cytochrome P450 3A5*8 protein. 